\title{
Policy Liberalism and Political Institutions
}

\author{
Chon-Kyun Kim*
}

\begin{abstract}
This paper examines the impacts of political institutions, especially a president's party affiliation and job performance, on the generosity of social welfare benefits, which are one of the characteristics of policy liberalism, through an investigation of U.S. social welfare expenditures. Findings indicate that a president's party affiliation is a key predictor of his policy preferences, agendas, and policy liberalism or conservatism despite institutional and political constraints, whereas a president's job performance, measured by either success on congressional votes or job approval, is not linked to the generosity of social welfare benefits. In an age of global capitalism undergoing radical changes in the political and economic environment, however, a president's party affiliation is not a crucial indicator of policy preferences or policy liberalism/conservatism. Additionally, political leaders' policy preferences and tools appear to determine more significantly the destiny of welfare programs than a president's job performance or economic conditions like unemployment.
\end{abstract}

Keywords: liberalism, social welfare, public policy, political party, president

Institutional arrangements generally matter, although the effects of institutional arrangements on governmental effectiveness and governmental capabilities are contingent (Weaver and Rockman 1993). The U.S. government is based on the separation of powers and the sharing of power between the executive, legislative, and judicial branches. Compared to other Western developed democracies, particularly parliamentary systems, the U.S. political system makes it more difficult for presidents to achieve their policy agendas. Under the separation of powers and divided government, a president relies on persuasion, bargaining, and coalition building, as Neustadt (1990) pointed out. Divided government "exacerbates some problems of governance, especially the problem of setting priorities" (Weaver and Rockman 1993, 451). Some presiden-

* Chon-Kyun Kim is assistant professor of public administration at Texas A\&M University, Corpus Christi, Texas, USA. His research interests include public policy, organization theory, human resources management, and digital government. E-mail: jckim1999@yahoo.com.

Manuscript received May 31, 2010; out for review June 15, 2010; review completed June 30, 2010; accepted July 7, 2010.

The Korean Journal of Policy Studies, Vol. 25, No. 2 (2010), pp. 1-12.

(C) 2010 by the GSPA, Seoul National University 
tial agendas tend to fail, while most represent a constituency's interests and preferences. Among the examples of policy failure in the Clinton administration were health care reform and regulation of cigarette companies.

Is a Democratic president linked to policy liberalism against the backdrop of institutional and political constraints? Does a president's job performance or legislative liberalism correlate with policy liberalism? Those research questions are directly or indirectly addressed in this study. The objective of this study is to empirically examine the relationship between political institutions, especially a president's party affiliation and job performance, and policy liberalism through an investigation of U.S. social welfare expenditures. After reviewing the literature on policy liberalism and political institutions, this study conducts multivariate statistical analyses on social welfare spending, and analyzes and discusses findings. This study is important in terms of articulating possible explanations for the linkage between political institutions and policy liberalism and testing the relationships between a president's party, his job performance, legislative liberalism, and policy liberalism.

\section{PERSPECTIVES ON POLICY LIBERALISM AND POLITICAL INSTITUTIONS}

Policy liberalism differs from classical liberalism and neoliberalism with regards to the role of government and economic principles. Classical liberalism advocates a minimal government that does not intervene in economic matters, arguing that markets will be sustained by an "invisible hand," as the classical economist Adam Smith asserted. Supporting the ideas of classical liberalism, neoclassical liberalism aims to transform an ineffective economic system through privatization, deregulation, decentralization, and globalization of the capitalist economy, in addition to downsizing or restructuring government functions and programs. Since the late 1970s, neoliberalism has become the popular economic ideology in advanced industrial countries, including the United States and the United Kingdom, where Thatcherism and Reaganism, both varieties of neoliberalism, emerged as alternatives to the modern welfare state (see Campbell and Pedersen 2001).

Policy liberalism refers to the extent to which a society adopts liberal policies related to social welfare systems, progressive tax structures, fair standards for economic activities, and protection for racial and gender minorities, disadvantaged people, and consumers. Historically, the welfare state derives from policy liberalism in which the government offers relief in cases of social disorder, such as massive unemployment during the Great Depression of the 1930s (Piven and Cloward 1971). With the positive 
role of government associated with modern liberalism, policy liberalism drives the government to distribute or redistribute wealth and resources according to need, regulate an unjust economic system, and protect disadvantaged people. However, public choice theorists criticize policy liberalism, which they say leads to an unlimited expansion of government size. Dye (1990) pointed out that the median voter model contributes to overspending and overtaxing and that government size should be reduced by public choice.

National or state policy liberalism has been explored from several perspectives. First, state policy liberalism has been discussed with reference to mobilization of lower-class voters, class bias of the electorate, and state liberalism. Wright et al. (1987) indicated that state liberalism and citizen preferences are key predictors of state policy: for instance, the more liberal citizens are, the more the state spends per pupil on education. Investigating the impacts of public preferences on public expenditures in the United States, the United Kingdom, and Canada, Soroka and Lim (2003) and Soroka and Wlezien (2005) found that public preferences are directly linked to public expenditures on services such as health care. Hill et al. (1995) showed that lower class voting correlates with generous state welfare policies. Barrilleaux (1997) revealed that electoral competition, legislative party strength, legislative liberalism, and liberal public opinion are associated with state policy liberalism. Hill and Hinton-Anderson (1995) indicated that lower-class voter mobilization, party competition, elite liberalism, and mass liberalism play a significant role in determining the degree of policy liberalism. However, Ringquist et al. (1997) pointed out that "neither party competition nor liberal control constitutes the linkage by which lower-class mobilization affects policy" (p. 344). In the global market system in which capital moves faster across territorial borders and countries compete more intensively, public preferences or liberal public opinion would not be a crucial predictor of policy liberalism.

Second, interest group politics might be a significant factor affecting policy liberalism. For instance, supporting labor, civil rights, and women's rights, the American Federation of Labor and Congress of Industrial Organizations, the National Association for the Advancement of Colored People, and the National Organization for Women advocate the interests of their liberal constituents and actively lobby Congress, which contributes to policy liberalism. The various studies on interest groups, however, have provided little room for presidential autonomy, because elected officials are regarded as agents of institutional arrangements. In contrast to elitism, pluralism tends to relegate political leadership to coordination of interest conflicts.

Finally, political parties significantly affect policy outcomes and the level of liberalism. Concerning the impact of political parties on policy outcomes, various studies have supported the mandate theory. Hibbs (1977) indicated that the government pur- 
sues macroeconomic policies in accordance with the economic interests and preferences of its class-defined core constituency. For instance, in budgetary and macroeconomic policies, Republican administrations are more likely to increase the defense budget and control inflation, whereas Democratic administrations tend to increase the social welfare budget and control unemployment (see Hibbs 1977; Tufte 1978). Those studies have examined the influence of political parties on government expenditures, particularly on social welfare and defense. Blais et al. (1993 and 1996) found that leftwing governments tend to spend a little more than right-wing governments. Boix (1997) noted that left-wing governments spend heavily on physical and human capital formation to raise the competitiveness of the economy, whereas right-wing governments rely instead on the private sector.

The party mandate theory suggests that political parties offer voters different government programs in an election and that the party getting the majority of the votes carries out its promised programs. In other words, competing parties propose their own programs to the voters, and the party that attracts the most voters forms a government to respond to the needs of its constituency. The party mandate theory links a constituency's interests and preferences with the behavior of elected public officials. Budge and Hofferbert (1990) found that although the importance of the party has declined in American politics, the occupancy of the White House connects party platform emphases to the priorities in federal spending for most areas of human services, such as education, health, and employment services.

For example, a Democratic administration supports funding for programs that benefit lower-income groups and labor, whereas a Republican administration supports funding for programs that benefit businesses and upper- and middle-income people. A president seeks to satisfy his core constituency's interests and preferences and to achieve his goals, such as reelection, congressional success, establishment of good public policies, and historical achievements (Light 1999). Meanwhile, a president's party affiliation is an important indicator of his preferences on public programs, budgeting, and personnel. Based on strong anticommunism and conservatism, President Ronald Reagan appointed ideologically pure conservatives to implement his conservative policies. By contrast, representing the interests of liberal constituents who are likely to be pro-labor and anti-business, President Barack Obama has pursued liberal policies such as reforming the health care system and the financial system and reducing carbon dioxide emissions. 


\section{DATA AND METHODS}

\section{Dependent Variable}

The dependent variable used in this study was policy liberalism. Since policy liberalism is a broad term covering various liberal policies, this study focuses on social welfare programs, such as social insurance, public aid, health and medical programs, veterans' programs, and public education and housing. Policy liberalism in this study was measured as the ratio of yearly total social welfare expenditures across all governments to gross domestic product. Social welfare expenditures in any one year, however, are largely a function of expenditures in previous years: in other words, there exists a serial correlation problem. The autocorrelation or multicollinearity problem in time series can be minimized through differencing, which is the measurement of the change between Xt and Xt-1 (see Mill 1990; Gujarati 1988). Accordingly, social welfare expenditures and gross domestic product are to be differenced. Data on social welfare expenditures and gross domestic product were obtained from the U.S. Department of Health and Human Services and the Economic Report of the President.

\section{Independent Variables}

The independent variables used in this study were president's party affiliation, president's job performance, legislative liberalism, and unemployment, which might determine the degree of policy liberalism. First, a president's party affiliation matters on the grounds that inter-party differences are more significant than intra-party differences, even if all Democratic presidents have different preferences on welfare programs (likewise for all Republican presidents). President's party affiliation is a dummy variable. The Republican Party was coded as 0 and the Democratic Party as 1 .

Second, a president's job performance, measured by either presidential success on congressional votes or presidential job approval, could have an impact on policy liberalism. Edwards and Wood (1999) examined the president's success in light of the issue attention of Congress and the mass media. Congressional votes are likely to be a buffer on presidential influence. Presidential success on congressional votes was computed by dividing successful votes by all votes. Every vote was given equal weight, regardless of its actual importance. When a committee kills a bill the president supports, this goes unrecorded in the vote. Presidential job approval is also measured by the Gallup poll, in which people are asked whether they approve or disapprove of the way the president is handling his job, and approvals are divided by the total number of responses. Presidential job approval ratings are affected by a variety of factors, includ- 
ing macroeconomic conditions, domestic and international events, and the mass media. Data on congressional votes and presidential approval ratings were obtained from the Congressional Quarterly Weekly Report.

Third, legislative liberalism - that is, Democratic control of Congress - could be a key predictor of policy liberalism in that Democratic control of the House and the Senate positively affects policy liberalism, whereas Republican control of the House and the Senate negatively affects it. Democratic control of both the House and the Senate was coded as 2, Democratic control of either the House or the Senate as 1, and Republican control of both the House and the Senate as 0. Data on the party control of the House or the Senate were obtained from the Congressional Quarterly Weekly Report. Additionally, the interaction variables between a president's party and presidential success on congressional votes, presidential job approval, or legislative liberalism are to be established, because there is a possibility that a president's party affiliation interacts with his job performance or legislative liberalism and that such an interaction reinforces policy liberalism or conservatism.

Finally, unemployment could have a significant impact on policy liberalism, because high unemployment rates drive the government to increase social welfare spending. In other words, the percentage of the labor force that is unemployed could have a direct relationship with policy liberalism. Data concerning unemployment rates were obtained from the U.S. Bureau of Labor Statistics. During the period covered by this study, there were seven presidents (three Democrats and four Republicans) from Lyndon Johnson through Bill Clinton. Table 1 shows a brief summary of indicators and measurement for the dependent and independent variables.

Table 1. Indicators and M easurement

\begin{tabular}{|c|c|}
\hline Dependent variable & $\begin{array}{l}\text { Policy liberalism (ratio of yearly total social welfare expenditures across all } \\
\text { governments to gross domestic product) }\end{array}$ \\
\hline Independent variables & $\begin{array}{l}\text { 1. President's party affiliation } \\
\text { (Republican presidents coded as 0, Democratic presidents coded as 1) } \\
\text { 2. President's job performance } \\
\text { a. Presidential success on congressional votes } \\
\text { (successful votes divided by all votes) } \\
\text { b. Presidential job approval (approvals divided by all responses) } \\
\text { 3. Legislative liberalism (Democratic control of both houses coded as 2, } \\
\text { Democratic control of one house coded as 1, and Republican control of both } \\
\text { houses coded as 0) } \\
\text { 4. Unemployment (percentage of labor force unemployed) }\end{array}$ \\
\hline
\end{tabular}




\section{ANALYSIS AND FINDINGS}

Table 2 demonstrates the impacts of a president's party affiliation and job performance, legislative liberalism, and unemployment on social welfare spending. The findings indicate that Democratic presidents and Democratic control of Congress are linked to the generosity of social welfare benefits, whereas a president's job performance, unemployment, and the interaction variables between a president's party and his job performance or legislative liberalism are not related to social welfare expenditures. Not surprisingly, Democratic presidents and Democratic control of Congress directly correlate with the generosity of social welfare benefits. Surprisingly, economic indicators like unemployment rates and a president's job performance (measured by either presidential success on congressional votes or presidential job approval) do not significantly affect social welfare expenditures.

Table 2. Impacts of Political Institutions on Policy Liberalism

\begin{tabular}{lllc}
\hline Variables & b & Sb & t \\
\hline President's Party & $.056^{*}$ & .026 & 2.153 \\
\hline Presidential Success & .000 & .000 & .125 \\
\hline Presidential Approval & .000 & .000 & .103 \\
\hline Legislative Liberalism & $.012^{* *}$ & .004 & 3.0 \\
\hline Unemployment & .001 & .000 & 1.175 \\
\hline President's Party X Presidential Success & .000 & .000 & .079 \\
\hline President's Party X Presidential Approval & .000 & .000 & .098 \\
\hline President's Party X Legislative Liberalism & .007 & .022 & .388 \\
\hline Constant & $.044^{*}$ & .018 & 2.444 \\
\hline Adjusted R2 & .184 & & \\
\hline $\mathrm{F}(8,21)=$ & 1.818 & & \\
\hline Standard Error of Estimate & .006 & & \\
\hline $\mathrm{N}$ & 34 & & \\
\hline
\end{tabular}

Note: Unstandardized OLS estimates.

All significance tests are one-tailed: ${ }^{*} p<05, * * p<.01$

Control by a single party of the presidency and Congress has significant impacts on policy liberalism or conservatism. Coleman $(1999,821)$ found that "unified government produces greater quantities of significant enactments and is more responsive to the public mood than is divided government." Edwards et al. $(1997,545)$ noted that "presidents oppose significant legislation more often under divided government." As 
far as funding for social welfare programs is concerned, unified government is more effective than divided government. Democrats have controlled both the House and the Senate since World War II except for during the Reagan administration and some years of the Clinton and George W. Bush administrations. Social welfare expenditures were likely to decline during Republican control of either the House or the Senate and during the Reagan years.

Table 2 also indicates that Democratic control of Congress is more significant for social welfare expenditures than Democratic control of the White House, whereas Democratic control of the White House has a greater impact on social welfare expenditures than Democratic control of Congress. The slope coefficient of Democratic control of the White House is .056, and the slope coefficient of Democratic control of Congress is .012; the p-level of Democratic control of the White House is .045, and the p-level of Democratic control of Congress is .007. In other words, the level of funding for social welfare programs is determined by Congress rather than the president, because Congress authorizes it even if a president initiates the legislation.

Further, a president's job performance, measured either by success on congressional votes or by public approval, is not necessarily linked to funding for public welfare programs. A Democratic or Republican president's high success on congressional votes or high public approval ratings has not necessarily led to greater or lower funding for social welfare programs. While Johnson and Clinton maintained a relatively high popularity, Johnson significantly expanded welfare programs under a unified government, and Clinton significantly cut welfare programs under both unified and divided governments. Most Democratic and Republican presidents have tended to have different levels of impacts on welfare programs because they have different levels of belief in liberalism or conservatism or because they are affected by different political, social, and economic situations. A president's values, beliefs, and ideology seem to have greater impacts on welfare programs than a president's popularity or success.

Unemployment rates are one of the most important economic indicators to which political leaders should respond through appropriate fiscal or monetary policies. Unemployment rates were relatively low during the Johnson years, but welfare programs dramatically expanded during those years. Conversely, unemployment rates were relatively high during the Reagan years, but many welfare programs were cut during those years. Economic depression tends to negatively affect reelection, and thus a chief executive is willing to boost the economy through fiscal or monetary policies, as a number of studies (for example, Tufts 1978) have suggested. However, the methods of assisting the unemployed rely on a chief executive's policy preferences and tools-for example, utilizing the private sector and local government, utilizing publicprivate partnerships, or expanding public welfare programs, as presidents from John- 
son to Obama have shown. Political leaders' policy preferences and tools for helping the unemployed can determine the level of funding for welfare benefits, even if political leaders' preferences are constrained more often by citizen preferences.

\section{POLICY IMPLICATIONS}

Past studies on policy liberalism indicate that liberal public opinion, lower-class voter mobilization, party competition, party mandates, elite liberalism, and legislative liberalism correlate with policy liberalism (see Wright et al. 1987; Barrilleaux 1997; Soroka and Lim 2003; Soroka and Wlezien 2005). In the age of global capitalism, in which capital moves faster across territorial borders and countries compete more intensively, however, citizen preferences, liberal public opinion, and state liberalism are not likely to play a key role in determining policy liberalism. Since policy liberalism is a broad term covering various liberal policies, this study has focused on the generosity of social welfare benefits, which are one of the characteristics of policy liberalism. Also, this study has focused on the extent to which policy liberalism is determined by a president's job performance, which is not properly explored in the literature on policy liberalism, as well as a president's party affiliation. Linking a constituency's preferences with the behavior of elected officials, the mandate theory shows how the occupancy of the White House is related to priorities in federal spending for most areas of human services (see Budge and Hofferbert 1990). The mandate theory, however, does not show the extent to which a president's job performance contributes to policy liberalism or conservatism.

The findings of this study indicate that a president's party affiliation is a key predictor of his policy preferences, agendas, and policy liberalism or conservatism, despite institutional and political constraints, whereas a president's job performance, measured by either success on congressional votes or job approval, is not linked to the generosity of social welfare benefits. Political leaders' policy preferences and tools appear to determine the destiny of welfare programs more significantly than a president's job performance or economic conditions like unemployment. As the mandate theory indicates, a president's party is one of the key political institutions through which his core constituency's preferences and interests are represented by establishing and budgeting public programs. However, the impact of a president's party affiliation on policy liberalism or conservatism is gradually diminishing due to decreasing ideological and policy differences between the two major political parties, continuously divided government, and declining trust in government. A president's party affiliation is not a crucial indicator of his policy preferences and tools regarding social welfare 
programs in the twenty-first century. Instead, policy tools or alternatives based on more market-oriented mechanisms rather than party identification are likely to determine the future of welfare programs.

More importantly, radical changes in the domestic or international political and economic environment are significantly affecting the relationship between political institutions and policy liberalism and conservatism. First, the War on Terror has dramatically transformed American foreign and domestic policies since 2001, in both the (George W.) Bush and Obama administrations. Regardless of a president's party affiliation or congressional partisanship, political leaders have focused on fighting domestic and international terrorists at the expense of freedom, privacy, human rights, lowerclass interests, or constituents' preferences. Defense and homeland security programs have been often executed at the expense of social welfare programs during these years.

Second, with the revolution in information technology and the advent of global capitalism, globalization has significantly changed political and economic principles and structures that played an important role in maintaining American society for a long time. No matter what elected officials' party affiliations or constituents' interests, elected officials have been vulnerable to global pressures and forces in which the logic of capital and markets often prevails over democratic principles and influences the response to emerging contemporary issues such as climate change, income inequality, and the need for environmental and ecological protection, clean energy, trade openness, and sustainable development (see Kim 2008).

Third, the economic depression and the national debt have been a huge burden not only to ordinary people but also to political leaders around the world since the housing and credit bubble burst. Responding to the global economic and financial crisis, the Obama administration has focused on reforming the financial system and stimulating the economy, while the Tea Party, a grass-roots conservative movement, has increasingly appealed to those who prefer lower taxes and small government and has remarkably weakened the base of the two major parties' support. Political actors have no choice but to adjust to new political and economic circumstances, irrespective of their ideological differences or policy preferences.

\section{REFERENCES}

Barrilleaux, C.. 1997. A test of the independent influences of electoral competition and party strength in a model of state policy-making. American Journal of Political Science 41:1462-66.

Blais, A., D. Blake, and S. Dion. 1993. Do parties make a difference? Parties and the 
size of government in liberal democracies. American Journal of Political Science 37:40-62.

Blais, A., D. Blake, and S. Dion. 1996. Do parties make a difference? A reappraisal. American Journal of Political Science 40:514-20.

Boix, C. 1997. Political parties and the supply side of the economy: The provision of physical and human capital in advanced economies, 1960-90. American Journal of Political Science 41:814-45.

Budge, I., and R. I. Hofferbert. 1990. Mandates and policy outputs: U.S. party platforms and federal expenditures. American Political Science Review 84:111-31.

Campbell, J. L., and O. K. Pedersen, eds. 2001. The rise of neoliberalism and institutional analysis. Princeton, NJ: Princeton University Press.

Coleman, J. J. 1999. Unified government, divided government, and party responsiveness. American Political Science Review 93:821-35.

Congressional Quarterly. 2000. Congressional Quarterly weekly report. Washington, DC: Congressional Quarterly.

Dye, T. R. 1990. American federalism. Lexington, MA: Lexington Books.

Edwards, G. C., III, A. Barrett, and J. Peake. 1997. The legislative impact of divided government. American Journal of Political Science 41:545-63.

Edwards, G. C., III, and B. D. Wood. 1999. Who influences whom? The president, Congress, and the media. American Political Science Review 93:327-44.

Gujarati, D. N. 1988. Basic econometrics. 2nd ed. New York: McGraw-Hill Book Company.

Hibbs, D. 1977. Political parties and macro-economic policies. American Political Science Review 71:1467-87.

Hill, K. Q., and A. Hinton-Anderson. 1995. Pathways of representation: A causal analysis of public opinion-public policy linkages. American Journal of Political Science 39:924-35.

Hill, K. Q., J. E. Leighley, and A. Hinton-Anderson. 1995. Lower-class mobilization and policy linkage in the U.S. states. American Journal of Political Science 39:75-86.

Kim, C.-K. 2008. Public Administration in the Age of Globalization. International Public Management Review 9:39-54.

Light, P. 1999. The president's agenda: Domestic policy choice from Kennedy to Clinton. 3rd ed. Baltimore, MD: Johns Hopkins University Press.

Mills, T. C. 1990. Times series techniques for economists. Cambridge: Cambridge University Press.

Neustadt, R. E. 1990. Presidential power and the modern presidents: The politics of leadership from Roosevelt to Reagan. New York: Free Press. 
Piven, F. F., and R. A. Cloward. 1971. Regulating the poor: The functions of public welfare. New York: Vintage Books.

Ringquist, E. J., K. Q. Hill, J. E. Leighley, and A. Hinton-Anderson. 1997. Lowerclass mobilization and policy linkage in the U.S. states: A correction. American Journal of Political Science 41:339-44.

Soroka, S. N., and E. Lim. 2003. Issue definition and the opinion-policy link: Public preferences and health care spending in the US and UK. British Journal of Politics and International Relations 5(4):576-93.

Soroka, S. N., and C. Wlezien. 2005. Opinion-policy dynamics: Public preferences and public expenditure in the United Kingdom. British Journal of Political Science 35:665-89.

Tufts, E. 1978. Political control of the economy. Princeton, NJ: Princeton University Press.

U.S. Bureau of Labor Statistics. 2000. Labor force statistics from the current population survey. Washington, DC: U.S. Government Printing Office.

U.S. Department of Health and Human Services. 2000. Social Security bulletin. Washington, DC: U.S. Government Printing Office.

U.S. Executive Office of the President. 2000. Economic report of the president. Washington, DC: U.S. Government Printing Office.

Weaver, R. K., and B. A. Rockman. 1993. When and how do institutions matter? In Do institutions matter?, ed. R. K. Weaver and B. A. Rockman (pp. 445-61). Washington, DC: Brookings Institution.

Wright, G. C., R. S. Erikson, and J. P. MacIver. 1987. Public opinion and policy liberalism in the American states. American Journal of Political Science 31:980-1001. 